\title{
Role of Appetite-Regulating Peptides in the Pathophysiology of Addiction: Implications for Pharmacotherapy
}

\author{
Jörgen A. Engel · Elisabet Jerlhag
}

Published online: 24 June 2014

(C) The Author(s) 2014. This article is published with open access at Springerlink.com

\begin{abstract}
Food intake and appetite are regulated by various circulating hormones including ghrelin and glucagonlike-peptide 1 (GLP-1). Ghrelin, mainly released from the stomach, increases food intake, induces appetite, enhances adiposity as well as releases growth hormone. Hypothalamic "ghrelin receptors" (GHS-R1A) have a critical role in food intake regulation, but GHS-R1A are also expressed in reward related areas. GLP-1 is produced in the intestinal mucosa as well as in the hindbrain in response to nutrient ingestion. This gut-brain hormone reduces food intake as well as regulates glucose homeostasis, foremost via GLP-1 receptors in hypothalamus and brain stem. However, GLP-1 receptors are expressed in areas intimately associated with reward regulation. Given that regulation of food and drug intake share common neurobiological substrates, the possibility that ghrelin and GLP-1 play an important role in reward regulation should be considered. Indeed, this leading article describes that the orexigenic peptide ghrelin activates the cholinergic-dopaminergic reward link, an important part of the reward systems in the brain associated with reinforcement and thereby increases the incentive salience for motivated behaviors via this system. We also review the role of ghrelin signaling for reward induced by alcohol and addictive drugs from a preclinical, clinical and human genetic perspective. In addition, the recent findings showing that GLP-1 controls reward induced by alcohol, amphetamine, cocaine and nicotine in rodents are over-
\end{abstract}

J. A. Engel · E. Jerlhag ( $₫)$

Department of Pharmacology, Institute of Neuroscience and Physiology, The Sahlgrenska Academy at the University of Gothenburg, POB 431, 40530 Gothenburg, Sweden e-mail: elisabet.jerlhag@pharm.gu.se viewed herein. Finally, the role of several other appetite regulatory hormones for reward and addiction is briefly discussed. Collectively, these data suggest that ghrelin and GLP-1 receptors may be novel targets for development of pharmacological treatments of alcohol and drug dependence.

\section{Key Points}

The data presented in this leading article collectively show that the orexigenic peptide ghrelin actives the cholinergic-dopaminergic reward link, an important part of the reward systems in the brain, implying that ghrelin may increase the incentive salience of motivated behaviors.

Central ghrelin signaling, as shown by ghrelin administration, ghrelin knockout mice as well as by pharmacological or genetical suppression of the ghrelin receptor (GHS-R1A), is required for alcohol mediated behaviors as well as for drug-induced reward in rodents, which is verified in human genetics studies.

In addition to regulation of food intake and glucose homeostasis, recent and novel data show that glucagon-like-peptide 1, another endocrine signal from the gut, mediates reward induced by alcohol, amphetamine, cocaine and nicotine in rodents.

In conclusion, peptides regulating appetite, such as ghrelin and GLP-1, may therefore constitute novel targets for development of pharmacological treatment strategies for addictive behaviors such as alcohol use disorders. 


\section{Appetite Regulating Peptides}

As discussed in several previous reviews, food intake and appetite are regulated by various circulating hormones and neuropeptides (see e.g. [1-3]). These signals include those produced by the gastrointestinal tract, such as ghrelin, peptide YY (3-36), oxyntomodulin, cholecystokinin and glucagon-like peptide-1 (GLP-1), in the brain, including galanin, orexin, neuropeptide Y (NPY), as well as those produced by adipose tissue e.g. adiponectin, leptin, interleukin-6 (for review see e.g. [2, 3] for overviews). Interestingly, these hunger-controlling hormones inform the present energy homeostasis to diverse neurobiological circuits, especially the hypothalamus, causing a physiological response (for review see e.g. [2,3] for overviews). For several of these hunger-regulating hormones an increasing number of data, as reviewed herein, show that they also target brain areas intimately associated with reward and addiction. Taken together with the findings that regulation of food and drug intake share common neurobiological substrates $[4,5]$, the possibility that endocrine signals from the gut traditionally known to regulate food intake, energy and body weight homeostasis may play a role in reward regulation should be considered. Given that ghrelin and GLP-1 are fairly new modulators of druginduced reward the involvement of these appetite-regulating peptides in reward and addiction processes are reviewed in this leading article. In addition, the role of several other hunger hormones in drug related behaviors is briefly discussed.

\section{Ghrelin}

\subsection{An Overview of Ghrelin and Its Function Within the Central Nervous System}

Ghrelin, a 28-amino acid peptide, is mainly produced in and secreted from the stomach and other peripheral tissues [6]. However, there might be some production in parts of the brain [7-9]. Ghrelin was initially found to be involved in the hypothalamo-pituitary growth axis by increasing the release of growth hormone [6]. Extensive research has since then shown that circulating ghrelin has physiological roles for food intake and appetite in rodents as well as in humans [1, 10-12]. In addition, ghrelin regulates meal initiation [13] and increased ghrelin levels correlate with hunger scores in healthy subjects [14]. The findings that ghrelin increases adiposity by a mechanism that includes decreased fat utilization $[15,16]$ suggested that "ghrelin receptors" [i.e. growth hormone secretagogue receptor (GHS-R1A)] could be pharmacological targets for treatment of obesity. Hypothalamic GHS-R1A were readily attributed to the ability of ghrelin to cause a release of growth hormone, but these receptors were later found to be important for ghrelin's effect on fat accumulation, food intake as well as energy balance [7]. Interestingly, ghrelin and its receptor have since then been attributed several other physiological roles. Thus, this hormone regulates glucose levels, stimulates prolactin secretion, influences sleep and acts on the cardiovascular system (for review see [17]) and stimulates gastric motility in rodents [18]. In addition, ghrelin influences memory formation via hippocampal GHS-R1A [19] and increases anxiety- and depression-like behavior in rodents [20]. The findings that GHS-R1A are expressed throughout the reward systems [21-23], raised the hypothesis that ghrelin may have a role in reward regulation.

\subsection{Ghrelin Activates the Cholinergic-Dopaminergic Reward Link}

An important part of the reward systems in the brain is the cholinergic-dopaminergic reward link. It encompasses a cholinergic afferent projection from the laterodorsal tegmental area (LDTg) onto the ventral tegmental area (VTA) dopamine cells together with the mesolimbic dopamine system [i.e. the dopamine neurons from the VTA to nucleus accumbens (NAc)] (for review see [24]). This reward link is intimately associated with the reinforcing properties of natural rewards and addictive drugs [25-28] (for review see [24, 29]). The data presented in this leading article collectively show that ghrelin actives the cholinergic-dopaminergic reward link, implying that ghrelin may increase the incentive salience of motivated behaviors (for overview see Table 1).

The first study showing that ghrelin activates the reward systems showed that intracerebroventricular administration of ghrelin increased accumbal dopamine release and caused a locomotor stimulation in mice [30]. These data were extended and corroborated by the findings showing that local infusion of ghrelin into either the VTA or LDTg causes a locomotor stimulation and accumbal dopamine release [31] and that ghrelin administration locally into the VTA increases the dopamine turnover in NAc in rodents [32]. Furthermore, it was recently showed that peripheral or intra-LDTg ghrelin administration concomitantly increases ventral tegmental acetylcholine as well as accumbal dopamine release and that this synchronous neurotransmitter release is blocked by systemic injection of a GHS-R1A antagonist [33]. The findings that GHS-R1A are expressed on cholinergic cells in the LDTg [34] as well as on dopaminergic neurons in the VTA [32] further support that ghrelin can activate the reward systems via local mechanisms within the VTA and LDTg. A possibility that 
Table 1 Summary of articles addressing the role of ghrelin and GLP-1 signaling in alcohol and drug addiction

\begin{tabular}{|c|c|}
\hline \multirow[t]{8}{*}{ Ghrelin administration } & $\begin{array}{l}\rightarrow \text { Activates the mesolimbic dopamine system, specifically the } \\
\text { cholinergic-dopaminergic reward link, in rodents }\end{array}$ \\
\hline & $\begin{array}{l}\rightarrow \text { Causes a focal activation of a network including ventral tegmental area, } \\
\text { nucleus accumbens and lateral hypothalamus in rats }\end{array}$ \\
\hline & $\rightarrow$ Increases novelty seeking in rats \\
\hline & $\begin{array}{l}\rightarrow \text { Increases alcohol intake in mice when administered into the third ventricle, } \\
\text { ventral tegmental area or laterodorsal tegmental area }\end{array}$ \\
\hline & $\rightarrow$ Slightly increases alcohol intake in alcohol naïve rats when administered peripherally \\
\hline & $\rightarrow$ Augments cocaine-induced hyperlocomotion and conditioned place preference in rats \\
\hline & $\rightarrow$ Increases the response in reward-related areas, such as nucleus accumbens, to food in humans \\
\hline & $\rightarrow$ Increases alcohol craving in alcohol dependent heavy-drinking individuals when injected intravenously \\
\hline Ghrelin knockout mice & $\begin{array}{l}\rightarrow \text { Display attenuation of alcohol-induced reward as measured by locomotor stimulation, conditioned } \\
\text { place preference and accumbal dopamine release }\end{array}$ \\
\hline $\begin{array}{l}\text { Prevention of ghrelin penetration } \\
\text { into the brain }\end{array}$ & $\rightarrow$ Does not alter the rewarding properties of alcohol or alcohol intake in rodents \\
\hline Plasma levels of ghrelin & $\rightarrow$ Are not different in high- and low-alcohol preferring rats \\
\hline & $\rightarrow$ Are lower in high-alcohol preferring rats than in low-alcohol preferring rats \\
\hline & $\rightarrow$ Are reduced by acute oral alcohol consumption in healthy volunteers \\
\hline
\end{tabular}

$\rightarrow$ Which are increased by fasting are suppressed by acute intravenous administration of alcohol in healthy nonsmoking social drinkers

$\rightarrow$ Are suppressed in active drinking in alcohol-dependent individuals

$\rightarrow$ Are increased in abstinent alcoholics

$\rightarrow$ Are higher in alcohol dependent individuals with high craving scores than in those with low craving scores
Jerlhag et al. [30]

Abizaid et al. [32]

Jerlhag et al. [31]

Jerlhag [36]

Jerlhag et al. [41]

Quarta et al. [37]

Jerlhag et al. [38]

Jerlhag et al. [33]

Wellman et al.

[39]

Hansson et al.

[50]

Jerlhag et al. [55]

Lyons et al. [61]

Wellman et al.

[86]

Davis et al. [87]

Malik et al. [40]

Leggio et al. [82]

Jerlhag et al. [60]

Bahi et al. [57]

Jerlhag et al. [62]

Landgren et al.

Szulc et al. [77]

Calissendorff

et al. [69]

Calissendorff

et al. [70]

Zimmerman et al.

Leggio et al. [73]

Addolorato et al. [74]

Kraus et al. [76]

Badaoui et al.

[75]

Kim et al. [78]

Kraus et al. [76]

Wurst et al. [79]

Addolorato et al. [74]

Wurst et al. [79]

Koopmann et al.

Leggio et al. [81]

Tessari et al. [88]

$\rightarrow$ Are increased in rats with high reinstatement of cocaine-seeking behavior

Landgren et al.

[83]

Landgren et al. [84]

Landgren et al. [85]

Landgren et al.

[84]

Suchankova et al. [95]

Landgren et al. [68] 
Table 1 continued

\begin{tabular}{|c|c|c|}
\hline \multirow{11}{*}{$\begin{array}{l}\text { "Ghrelin receptor" (GHS-R1A) } \\
\text { antagonist treatment }\end{array}$} & $\rightarrow$ Blocks the rewarding properties of alcohol in mice when administered centrally or peripherally & Jerlhag et al. [55] \\
\hline & $\rightarrow$ Decreases alcohol intake in rodents & Jerlhag et al. [55] \\
\hline & & $\begin{array}{l}\text { Kaur and } \\
\quad \text { Ryabinin [58] }\end{array}$ \\
\hline & & $\begin{array}{l}\text { Landgren et al. } \\
\quad[56]\end{array}$ \\
\hline & & Bahi et al. [57] \\
\hline & & $\begin{array}{l}\text { Suchankova et al. } \\
\text { [59] }\end{array}$ \\
\hline & $\rightarrow$ Decreases the motivation to consume alcohol as well as prevents relapse to alcohol drinking in rats & $\begin{array}{l}\text { Landgren et al. } \\
\text { [56] }\end{array}$ \\
\hline & $\rightarrow$ Blocks the rewarding properties of amphetamine, cocaine or nicotine in rodents & Jerlhag et al. [89] \\
\hline & & Abizaid et al. [91] \\
\hline & & $\begin{array}{l}\text { Clifford et al. } \\
\text { [90] }\end{array}$ \\
\hline & & $\begin{array}{l}\text { Wellman et al. } \\
\text { [94] }\end{array}$ \\
\hline \multirow[t]{3}{*}{$\begin{array}{l}\text { Ghrelin receptor (GHS-R1A) } \\
\text { knockout mice }\end{array}$} & $\begin{array}{l}\rightarrow \text { Display attenuation of the rewarding properties of alcohol as measured by locomotor stimulation, accumbal } \\
\text { dopamine release as well as conditioned place preference }\end{array}$ & Jerlhag et al. [55] \\
\hline & $\rightarrow$ Display a reduction in cocaine-induced locomotor stimulation and sensitization & $\begin{array}{l}\text { Clifford et al. } \\
\text { [90] }\end{array}$ \\
\hline & & Abizaid et al. [91] \\
\hline \multirow{6}{*}{$\begin{array}{l}\text { Ghrelin receptor (GHS-R1A) } \\
\text { expression }\end{array}$} & $\rightarrow$ Is detected in the nucleus accumbens, amygdala as well as on dopaminergic neurons in the ventral tegmental & Abizaid et al. [32] \\
\hline & area and on cholinergic neurons in the laterodorsal tegmental area in rats & $\begin{array}{l}\text { Dickson et al. } \\
\text { [34] }\end{array}$ \\
\hline & & $\begin{array}{l}\text { Landgren et al. } \\
\text { [23] }\end{array}$ \\
\hline & & Cruz et al. [66] \\
\hline & $\rightarrow$ Is altered in the ventral tegmental area following voluntary oral alcohol intake ( 3 or 10 months) & $\begin{array}{l}\text { Landgren et al. } \\
{[23]}\end{array}$ \\
\hline & & $\begin{array}{l}\text { Suchankova et al. } \\
\text { [59] }\end{array}$ \\
\hline \multirow[t]{6}{*}{$\begin{array}{l}\text { Administration of GLP-1 } \\
\text { analogues }\end{array}$} & $\rightarrow$ Decrease alcohol intake, alcohol seeking behavior and alcohol-induced reward in rodents & $\begin{array}{l}\text { Egecioglu et al. } \\
\text { [112] }\end{array}$ \\
\hline & & $\begin{array}{l}\text { Shirazi et al. } \\
\text { [113] }\end{array}$ \\
\hline & $\rightarrow$ Attenuate the rewarding properties of amphetamine and cocaine in rodents & $\begin{array}{l}\text { Erreger et al. } \\
\text { [115] }\end{array}$ \\
\hline & & $\begin{array}{l}\text { Graham et al. } \\
\text { [116] }\end{array}$ \\
\hline & & $\begin{array}{l}\text { Egecioglu et al. } \\
\text { [117] }\end{array}$ \\
\hline & $\rightarrow$ Prevent nicotine reward as well as block nicotine-induced expression of locomotor sensitization in mice & $\begin{array}{l}\text { Egecioglu et al. } \\
\text { [118] }\end{array}$ \\
\hline
\end{tabular}

ghrelin-induced reward could involve accumbal GHS-R1A should also be considered since GHS-R1A are expressed in this reward area [23].

Albeit ghrelin mainly is produced in the gastrointestinal tract [6] the possibility that circulating ghrelin reaches brain reward areas should be considered. Indeed, circulating ghrelin passes the blood brain barrier [35] and peripheral ghrelin administration induces a conditioned place preference, causes accumbal dopamine release and stimulates the locomotor activity in mice [36]. In support of the possibility that circulating ghrelin has central nervous effects are the findings showing that systemic ghrelin administration increase dopamine in the shell, rather than core, region of NAc [37]. The findings that VTA-infusion of a GHS-R1A antagonist blocks the ability of peripheral ghrelin to increase food intake [32] and activate the mesolimbic dopamine system [38], suggest that, albeit peripheral route of administration, the ability of ghrelin to cause reward involves central nervous system. This is further substantiated by imaging data revealing that peripheral ghrelin administration causes a focal activation of a network of VTA, NAc and lateral hypothalamus in rats [39]. In healthy volunteers systemic ghrelin administration increases the response in reward related areas such as NAc to visual food as shown in human functional magnetic resonance studies [40] (for overview see Table 1).

The mechanisms regulating the ability of ghrelin to active the cholinergic-dopaminergic reward link are being elucidated. The first study showed that specific subtypes 
( $\alpha 3 \beta 2, \beta 3$ and $\alpha 6)$ of the nicotinic acetylcholine receptor expressed within the VTA are crucial for ghrelin-induced reward [41]. Interestingly, antagonists to these subtypes also attenuate the reinforcing properties of alcohol in rodents [42-45] and reduce alcohol intake in heavydrinking smokers $[46,47]$. The findings that the ability of LDTg-ghrelin to increase accumbal dopamine is attenuated by an unselective nicotinic acetylcholine receptor antagonist into the VTA [33], further strengthen the contention that ghrelin activates the cholinergic-dopaminergic reward link. Other neurotransmitters may however be important for ghrelin-induced reward since the activity of mesolimbic dopaminergic neurons is controlled by various afferents. In support are the findings that a NMDA receptor antagonist, but not orexin or opioid receptor antagonist, attenuates ghrelin's ability to increase accumbal dopamine release, condition a place preference and cause a locomotor stimulation in mice [38]. Ghrelin increased food reward is modulated by NPY Y1 and opioid receptors in mice [48]. The findings that the mesolimbic dopamine system increases the incentive salience of motivated behaviors [49] and that ghrelin increases novelty seeking behavior in rodents and men [50] collectively imply that ghrelin signaling may influence the rewarding and motivational properties of addictive drugs and behavior.

\subsection{The Role of Ghrelin Signaling in Alcohol Addiction}

The findings that food deprivation augments drug reinforcement as well as increase self-administration of addictive drugs in rodents [51, 52] further support the hypothesis that common neurobiological mechanisms regulate food and drug reward [4, 5]. This is further substantiated by the findings that co-morbidities between alcohol use disorder and compulsive over eating in humans are common $[53,54]$. As reviewed herein ghrelin, and its receptor have been suggested to be a gut-brain hormone of importance for addiction (for overview see Table 1).

The first indication that ghrelin signaling regulates alcohol intake was from a study showing that peripheral or central administration of GHS-R1A antagonists (JMV2959 or BIM28163 respectively) reduces the intake of alcohol in mice consuming alcohol for 12 weeks [55]. In accordance are the findings that JMV2959 reduces high alcohol consumption in high-alcohol consuming Wistar as well as in alcohol-preferring (AA) rats [56], decreases voluntary alcohol consumption and preference in mice [57] and that peripheral administration of another GHS-R1A antagonist, D-Lys3-GHRP-6, reduces alcohol consumption in rats [58]. Moreover, acute systemic administration of the GHS-R1A antagonist, JMV2959, decreases alcohol intake in rats voluntarily consuming alcohol for two, five and ten months and the ability of JMV2959 to reduce alcohol intake is more pronounced over time [59]. It was also found that repeated administration of JMV2959 decreased alcohol intake without inducing tolerance or rebound increase in alcohol intake after treatment termination [59]. Further support for an important role for ghrelin signaling in alcohol dependence are the findings that the GHS-R1A antagonist (JMV2959) reduces the motivation to consume alcohol as measured in the operant lever pressing model [56] as well as prevents the alcohol deprivation effect which reflects rebound drinking in rats [59]. In addition to alcohol intake, it has been shown that suppressed GHSR1A function achieved by either genetical or pharmacological approaches (central or peripheral administration of a GHS-R1A antagonist (BIM28163 or JMV2959 respectively)) attenuates alcohol reward as measured by locomotor stimulation, conditioned place preference and accumbal dopamine release in mice [55].

Studies have also shown that central ghrelin administration, either into the third ventricle, the VTA or LDTg, increases alcohol intake in rats [55]. In accordance are the data showing that the alcohol-induced locomotor stimulation and dopamine release in NAc are attenuated in ghrelin knockout mice compared to wild type mice [60]. These data were later corroborated by others showing that ghrelin knockout mice have a disrupted alcohol reward as measured by locomotor stimulation, accumbal dopamine release and conditioned place preference [57]. Peripheral ghrelin administration only slightly increases alcohol intake in mice voluntarily consuming alcohol for only 3 days [61] implying that ghrelin signaling is more important in rodents exposed to alcohol for longer, rather than shorter, periods of time. Recent data show that Spiegelmer NOX-B11-2, which binds and neutralizes active (i.e. acylated) ghrelin in the periphery with high affinity and thus prevents its brain access, does not attenuate alcohol-induced reward in mice nor alcohol intake in rats [62], suggesting that circulating ghrelin in the plasma does not regulate alcohol intake or the rewarding properties of alcohol. On the contrary NOX-B112 reduced food intake in rats supporting a role for circulating ghrelin as a physiological regulator of food intake [62]. Given that ghrelin levels in the plasma are associated with alcohol craving (see later in Sect. 2.3) the possibility that circulating ghrelin is important for craving rather than reward should be considered. Taken together with the findings that ghrelin is produced centrally [7-9] it may be suggested that central ghrelin signaling regulates alcohol reward and consumption.

While previous studies pinpointed hypothalamic GHSR1A to be important for ghrelin mediated food intake [12], the findings that ghrelin increases alcohol intake via local injections into either the VTA or LDTg [55], suggest that 
the cholinergic-dopaminergic reward link is important for ghrelin signaling to regulate alcohol-mediated behaviors. GHS-R1A expression in the VTA is down regulated in high-compared to low-alcohol consuming rats supporting such a contention [59]. It has been shown that GHS-R1A alters the sensitivity of the mesolimbic dopamine system via its ability to heterodimerize with dopamine D1- and D2-like receptors [63, 64] as well as via its constitutive activity [65]. The possibility that ventral tegmental GHS-R1A, via such mechanisms, reduces the ability of addictive drugs to activate the mesolimbic dopamine system and thereby plays an important role for reward processes and for development of alcohol use disorder should therefore be considered. Other mechanisms or areas may also mediate the ability of GHSR1A to regulate reward. Expression of GHS-R1A has been identified in other areas of the mesolimbic dopamine system such as the amygdala $[23,66]$. It was recently revealed that ghrelin modulates GABAergic transmission in the rat amygdala by increasing inhibitory postsynaptic potential amplitudes in both naive and alcohol-dependent rats via pre- and post-synaptic mechanisms. Specifically, acute alcohol perfusion occluded the ghrelin-induced increase in GABAergic transmission whereas after repeated alcohol perfusion an enhanced ghrelin-induced inhibitory postsynaptic potential was observed in naïve, but not alcoholdependent rats. Application of GHS-R1A antagonists revealed tonic facilitatory activity of the GHS-R1A on GABAergic transmission in amygdala [66]. Further studies have shown that acute central administration of ghrelin increased serotonergic turnover as well as the expression of serotonin receptors in the amygdala in mice [67], suggesting that ghrelin signaling within the amygdala may regulate anxiety like behaviors.

There is a possibility that the orexigenic peptide reduces alcohol intake due to alcohol's caloric rather than rewarding properties. This appears less likely since the GHS-R1A antagonist JMV2959 reduces the intake of saccharine, another reward without calories [68], suppresses parameters strictly reflecting reward namely locomotor stimulation and conditioned place preference [55] as well as attenuates reward induced by other addictive dugs without caloric content (see Sect. 2.4).

Studies showing alterations in plasma levels of ghrelin in patients with alcohol dependence as well as in highand low-alcohol preferring rats support a role for ghrelin signaling in alcohol mediated behaviors. Initially it was shown that acute oral alcohol intake reduces the secretion of ghrelin in healthy volunteers [69-71]. Interestingly, the reduction of ghrelin by acute oral alcohol intake is not affected by gastroprotective sucralfate, implying that the appetite-stimulating effect of alcohol is not mediated by ghrelin [72]. The findings that acute intravenous administration of alcohol in healthy nonsmoking social drinkers suppresses fasting-induced increase in ghrelin, but does not alter circulating ghrelin levels, suggest that alcohol may act directly in the stomach by preventing the release/ secretion of ghrelin as well as via systemic effects in humans [73]. In line are also the findings that active drinking in alcohol-dependent individuals suppresses both ghrelin levels and fundic ghrelin production [74-76]. In support are the data from a rodent study showing that high-alcohol preferring rats have lower plasma levels of ghrelin than low-alcohol preferring rats do [77]. However this was not verified in another study showing no difference between ghrelin levels in high- and low-alcohol preferring rats [56]. In abstinent alcoholics several studies have shown that the levels of ghrelin are increased [76, 78]. This was also shown in abstinent female alcoholics [79]. Moreover, higher ghrelin levels correlate with higher craving levels in patients with alcohol use disorder [74, 79], suggest that ghrelin may increase the incentive value of motivated behaviors. Supportively, a recent study demonstrated that the plasma concentration of active ghrelin (previous studies have investigated total ghrelin) was positively correlated to alcohol craving and that the plasma levels of active ghrelin increased significantly during early abstinence [80]. In support are the findings showing that the baseline ghrelin levels correlate with self-reported craving scores in alcohol dependent individuals and that blood ghrelin levels are increased in alcohol dependent subjects who abstained from alcohol when compared to non-abstinent alcohol dependent subjects [81]. I in support of ghrelin playing a role in the neurobiology of alcohol craving are the recent data showing that intravenous administration of exogenous ghrelin increases alcohol craving in alcohol-dependent heavy-drinking individuals [82]. In addition, human genetic data show that high alcohol consumption in humans is associated with a single nucleotide polymorphism in the GHS-R1A gene [83]. Data from a cohort of Swedish females with alcohol dependence show that paternal alcohol dependence as well as with type II alcohol dependence is associated with haplotypes of the preproghrelin and GHS-R1A genes [84]. Moreover, polymorphisms of the ghrelin signaling system are associated with important personality traits of individuals with alcohol dependence namely decreased self-directedness and alterations in self-transcendence [85].

\subsection{The Role of Ghrelin Signaling in Drug Dependence}

Data from several publications reviewed herein suggest that ghrelin signaling has an important role for reward in general (for overview see Table 1). It was initially showed that peripheral ghrelin administration augments cocaineinduced locomotor stimulation [86] as well as conditioned 
place preference to cocaine in rats [87]. In accordance are the data showing a positive correlation between elevated levels of ghrelin and increased cocaine seeking behavior in rats [88]. Pharmacological suppression of GHS-R1A by means of JMV2959 reduces the rewarding properties of amphetamine and cocaine as measured by locomotor stimulation, accumbal dopamine release and conditioned place preference [89]. In addition, either genetic or pharmacologic suppression of GHS-R1A attenuates cocaineinduced locomotor stimulation as well as sensitization in rats [90, 91]. Food restriction, which elevates ghrelin levels [92], augments amphetamine- and cocaine-induced hyperlocomotion, enhances cocaine-seeking behavior and increases self-administration of cocaine or amphetamine in rats [51]. Furthermore, the GHS-R1A antagonist JMV2959 decreases the rewarding properties of nicotine [93] as well as prevents nicotine induced locomotor sensitization in rodents [94]. Human genetic data show an association between a single nucleotide polymorphism in the GHSR1A gene and smoking as well as with amphetamine dependence $[84,95]$. Taken together a role of ghrelin and its receptor in the reinforcing properties of addictive drugs may be implied.

\section{Glucagon-Like Peptide 1 (GLP-1)}

\subsection{A Brief Overview of GLP-1 and Its Function Within the Central Nervous System}

GLP-1 is produced in the intestinal L-cells [96] as well as in the hindbrain [97] in response to nutrient ingestion [98]. Increasing evidence shows that central or peripheral GLP-1 administration reduces food intake in rodents and man [99-103]. In addition, this incretin peptide [104] regulates glucose-dependent insulin secretion [105], gastric emptying and glucagon secretion [106, 107]. GLP-1 analogues have therefore been approved for treatment of type II diabetes. Initial studies showed that hypothalamic as well as brainstem GLP-1 receptors are required for the anorexic and glucoregulatory effects of GLP-1 [99, 108, 109]. The findings that GLP-1 receptors are expressed through out the mesolimbic dopamine system [110] and that GLP-1 containing neurons project directly to the VTA and NAc [111], suggest that the role of GLP-1 extends beyond food intake and glucose regulation and may include reward regulation as reviewed in this leading article.

\subsection{Role of GLP-1 in the Pathophysiology of Addiction}

There are to date a few initial publications suggesting that GLP-1 receptors have a role in reward regulation (for overview see Table 1). Indeed, treatment with a GLP-1 analogue, exendin-4, at a dose with no effect per se, prevented the rewarding properties of alcohol as measured by locomotor stimulation and accumbal dopamine release in mice [112]. This initial study also showed that conditioned place preference, reflecting reward, for alcohol was attenuated by both acute and chronic treatment with exendin-4 in mice. Furthermore, exendin-4 treatment decreased alcohol intake, using the intermittent access $20 \%$ alcohol two-bottle-choice model, as well as reduced alcohol seeking behavior, using the progressive ratio test in the operant self-administration model, in rats [112]. These novel data imply that GLP-1 receptors could be pharmacological targets for treatment of alcohol dependence in man. The findings were later corroborated by others showing that exendin-4, by peripheral or local VTA infusion, decreases alcohol intake in rats and that systemic exendin-4 injection attenuated alcohol induced conditioned place preference in mice [113]. Moreover, gastric bypass, which reduces ghrelin and increases GLP1 plasma levels, reduces alcohol intake in both humans and rats [114]. In addition to alcohol, GLP-1 receptors appear to be important for reward induced by addictive drugs. Indeed, exendin-4 attenuates amphetamine-induced locomotor stimulation and cocaine-induced conditioned place preference in rodents $[115,116]$. In support are the recent data showing that exendin-4, attenuates the reinforcing properties of cocaine as well as amphetamine as measured by locomotor stimulation, accumbal dopamine release and conditioned place preference in mice [117]. In accordance are the findings that exendin-4, in addition to preventing nicotine reward, blocks nicotine-induced expression of locomotor sensitization in mice [118]. To investigate the role of GLP-1 receptors for drug addiction further additional studies are warranted. For instance the role of other GLP-1 analogues, including liraglutide and exendatide, on alcohol reward, alcohol intake, relapse to alcohol drinking, cue-induced relapse drinking should be investigated. In addition, the role of the enzyme, dipeptidyl peptidase-4, which eliminates GLP-1, for alcoholand drug-induced reward should be elucidated. Associations between plasma levels of GLP-1 and alcohol craving as well as alcohol use disorder should be studied. Associations between polymorphisms in GLP-1 related genes and alcohol dependence should be examined in human genetic studies. Given that GLP-1 analogues, such as exenatide and liraglutide, are approved for the treatment of diabetes type II these reviewed data are of clinical interest since GLP-1 analogues could be used in treatment of drug dependence. When used for addiction therapy the possibility that a reduced alcohol intake is driven by nausea, rather than abolished reward, should be considered. Reports show that treatment with GLP-1 analogues 
is associated with an increased risk of pancreatitis, which may be a concern for patients with alcohol use disorder whom already display a risk for pancreatitis. Another concern may be that these substances are administered by subcutaneous injection.

\section{Other Appetite-Regulating Hormones and Drug Related Behaviors}

In addition to ghrelin and GLP-1 several other gut-brain hormones traditionally known to control food intake have been shown to modulate the responses to drugs of abuse. In brief, inhibition of leptin pathways decreases preference for alcohol [119] and leptin increases alcohol intake [120] as well as enhances the motivation to consume alcohol following alcohol withdrawal [121]. Elevated leptin levels have been demonstrated in male alcoholics [122] as well as in high alcohol-preferring mice [123]. Initial studies showed that an orexin receptor antagonist reduced selfadministration of alcohol, prevents reinstatement of alcohol-seeking induced by both visual and olfactory cues in alcohol preferring rats [124] as well as attenuates stressinduced reinstatement for alcohol-seeking in Long-Evan rats [125]. Activation of orexin neurons is associated with context-driven renewal of alcohol-seeking in rats [126]. However, as reviewed elsewhere the role of orexin for alcohol-induced reward appears to be more complex (for review see [127]). Central administration of orexin reinstates cocaine, morphine as well as heroin seeking behavior [128-130]. In human studies, the plasma levels of the anorexigenic peptides leptin as well as orexin are associated with nicotine craving [131]. Administration of either of these peptides blocks reward induced by psychostimulant drugs [132-134]. It was initially shown that NPYdeficient mice show increased alcohol consumption, compared with wild-type mice [135]. In addition, a NPY2 antagonist suppresses alcohol intake in both naïve [136] and postdependent animals [137]. Local infusion of a viral vector designed to overexpress NPY into the amygdala reduces alcohol intake [138]. Moreover, NPY blocks the reinstatement of alcohol-seeking induced by yohimbine in rats [139]. The serum levels of adiponectin are significantly elevated in patients with alcohol dependence at admission for alcohol detoxification as well as after one week of withdrawal treatment [140]. This study also showed that alcohol craving was significantly associated with adiponectin [140]. In addition, cholecystokinin decreases alcohol intake in rodents [141-143]. In accordance are the data showing that a selective cholecystokinin-A receptor antagonist reduced the consumption of alcohol, whereas a specific cholecystokinin-B receptor antagonist decreases the intake of cocaine in rats [144]. In addition, central administration of the orexigenic peptide galanin increases whereas a galanin antagonist reduces alcohol intake in rats $[145,146]$.

\section{Conclusion}

Alcohol use disorder is one of the major causes of illness and death in society, and the economic costs are extensive (for review see [147, 148]). Today, only a few medications are approved for treatment of alcohol dependence and clinical trials suggest that the effect of these pharmacological agents is moderate (for review see [147, 148]). Furthermore, it is a heterogenous disorder where treatment possibly should be individualized. There is therefore a need for additional and more effective medications. This leading article presents a review of the data showing that gut-brain peptides such as ghrelin and GLP-1 appear to have a broader role than body weight homeostasis. Indeed, these hormones regulate alcohol as well as drug-induced reward and both GHS-R1A and GLP-1 receptors may therefore constitute novel targets for development of pharmacological treatment strategies for addictive behaviors such as alcohol use disorders.

Acknowledgment and conflict of interest The review article was supported by grants from the Swedish Research Council (grant no. 2009-2782 and K2010-80X-21496-01-6), The Swedish brain foundation, LUA/ALF (grant no. 148251) from the Sahlgrenska University Hospital, Alcohol research council of the Swedish alcohol retailing monopoly and the foundations of Adlerbertska, Fredrik and Ingrid Thuring, Tore Nilsson, Längmanska, Torsten and Ragnar Söderberg, Wilhelm and Martina Lundgren, Knut and Alice Wallenberg, Magnus Bergvall, Anérs, Jeansons, Åke Wiberg, Torsten Söderberg, the Swedish Society of Medicine and the Swedish Society for Medical Research. The funders had no role in collection and review of the data presented in this review article, decision to publish, or preparation of the manuscript. The funding sources do not alter our adherence to all CNS Drugs policies on sharing data and materials. J.A. Engel has received consulting fees as well as traveling support to conferences from Pfizer $\mathrm{AB}$ Sweden, Lundbeck $\mathrm{AB}$ Sweden and Actavis AB Sweden as well as has received payment from Lundbeck $\mathrm{AB}$ Sweden for writing a manuscript. E. Jerlhag has received a grant from NovoNordisk Foundation.

Open Access This article is distributed under the terms of the Creative Commons Attribution Noncommercial License which permits any noncommercial use, distribution, and reproduction in any medium, provided the original author(s) and the source are credited.

\section{References}

1. Egecioglu E, Jerlhag E, Salome N, et al. Ghrelin increases intake of rewarding food in rodents. Addict Biol. 2010;15(3):304-11.

2. Zheng H, Lenard NR, Shin AC, et al. Appetite control and energy balance regulation in the modern world: reward-driven brain overrides repletion signals. Int J Obes. 2009;33:S8-13. 
3. Fulton S. Appetite and reward. Frontiers Neuroendocrinol. 2010;31(1):85-103.

4. Thiele TE, Stewart RB, Badia-Elder NE, et al. Overlapping peptide control of alcohol self-administration and feeding. Alcohol Clin Exp Res. 2004;28(2):288-94.

5. Morganstern I, Barson JR, Leibowitz SF. Regulation of drug and palatable food overconsumption by similar peptide systems. Curr Drug Abuse Rev. 2011;4(3):163-73.

6. Kojima M, Hosoda H, Date Y, et al. Ghrelin is a growth-hormone-releasing acylated peptide from stomach. Nature. 1999;402(6762):656-60.

7. Cowley MA, Smith RG, Diano S, et al. The distribution and mechanism of action of ghrelin in the CNS demonstrates a novel hypothalamic circuit regulating energy homeostasis. Neuron. 2003;37(4):649-61.

8. Lu S, Guan JL, Wang QP, et al. Immunocytochemical observation of ghrelin-containing neurons in the rat arcuate nucleus. Neurosci Lett. 2002;321(3):157-60.

9. Mondal MS, Date Y, Yamaguchi $\mathrm{H}$, et al. Identification of ghrelin and its receptor in neurons of the rat arcuate nucleus. Regul Pept. 2005;126(1-2):55-9.

10. Wren AM, Seal LJ, Cohen MA, et al. Ghrelin enhances appetite and increases food intake in humans. J Clin Endocrinol Metab. 2001;86(12):5992.

11. Wren AM, Small CJ, Abbott CR, et al. Ghrelin causes hyperphagia and obesity in rats. Diabetes. 2001;50(11):2540-7.

12. Wren AM, Small CJ, Ward HL, et al. The novel hypothalamic peptide ghrelin stimulates food intake and growth hormone secretion. Endocrinology. 2000;141(11):4325-8.

13. Cummings DE, Purnell JQ, Frayo RS, et al. A preprandial rise in plasma ghrelin levels suggests a role in meal initiation in humans. Diabetes. 2001;50(8):1714-9.

14. Cummings DE, Frayo RS, Marmonier C, et al. Plasma ghrelin levels and hunger scores in humans initiating meals voluntarily without time- and food-related cues. Am J Physiol Endocrinol Metab. 2004;287(2):E297-304.

15. Tschop M, Smiley DL, Heiman ML. Ghrelin induces adiposity in rodents. Nature. 2000;407(6806):908-13.

16. Theander-Carrillo C, Wiedmer P, Cettour-Rose P, et al. Central ghrelin infusion regulates adipocyte glucose and lipid metabolism in rats. Int J Obes. 2006;30:S69.

17. van der Lely AJ, Tschop M, Heiman ML, et al. Biological, physiological, pathophysiological, and pharmacological aspects of ghrelin. Endocr Rev. 2004;25(3):426-57.

18. Masuda Y, Tanaka T, Inomata N, et al. Ghrelin stimulates gastric acid secretion and motility in rats. Biochem Biophys Res Commun. 2000;276(3):905-8.

19. Diano S, Farr SA, Benoit SC, et al. Ghrelin controls hippocampal spine synapse density and memory performance. Nat Neurosci. 2006;9(3):381-8.

20. Hansson C, Haage D, Taube M, et al. Central administration of ghrelin alters emotional responses in rats: behavioural, electrophysiological and molecular evidence. Neuroscience. 2011;180: 201-11.

21. Guan XM, Yu H, Palyha OC, et al. Distribution of mRNA encoding the growth hormone secretagogue receptor in brain and peripheral tissues. Mol Brain Res. 1997;48(1):23-9.

22. Zigman JM, Jones JE, Lee CE, et al. Expression of ghrelin receptor mRNA in the rat and the mouse brain. J Comp Neurol. 2006;494(3):528-48.

23. Landgren S, Engel JA, Hyytia P, et al. Expression of the gene encoding the ghrelin receptor in rats selected for differential alcohol preference. Behav Brain Res. 2011;221(1):182-8.

24. Larsson A, Engel JA. Neurochemical and behavioral studies on ethanol and nicotine interactions. Neurosci Biobehav Rev. 2004;27(8):713-20.
25. Di Chiara G, Imperato A. Preferential stimulation of dopamine release in the nucleus accumbens by opiates, alcohol, and barbiturates: studies with transcerebral dialysis in freely moving rats. Ann N Y Acad Sci. 1986;473:367-81.

26. Weiss F, Lorang MT, Bloom FE, et al. Oral alcohol selfadministration stimulates dopamine release in the rat nucleus accumbens: genetic and motivational determinants. J Pharmacol Exp Ther. 1993;267(1):250-8.

27. Wise RA, Rompre PP. Brain dopamine and reward. Annu Rev Psychol. 1989;40:191-225.

28. Engel JA, Fahlke C, Hulthe P, et al. Biochemical and behavioral evidence for an interaction between ethanol and calcium channel antagonists. J Neural Transm. 1988;74(3):181-93.

29. Soderpalm B, Ericson M. Neurocircuitry involved in the development of alcohol addiction: the dopamine system and its access points. Curr Top Behav Neurosci. 2013;13:127-61.

30. Jerlhag E, Egecioglu E, Dickson SL, et al. Ghrelin stimulates locomotor activity and accumbal dopamine-overflow via central cholinergic systems in mice: implications for its involvement in brain reward. Addict Biol. 2006;11(1):45-54.

31. Jerlhag E, Egecioglu E, Dickson SL, et al. Central administration of ghrelin stimulates parameters associated with reward. Nordic J Psychiatry. 2007;61(6):497-8.

32. Abizaid A, Liu ZW, Andrews ZB, et al. Ghrelin modulates the activity and synaptic input organization of midbrain dopamine neurons while promoting appetite. J Clin Invest. 2006;116(12): 3229-39.

33. Jerlhag E, Janson AC, Waters S, et al. Concomitant release of ventral tegmental acetylcholine and accumbal dopamine by ghrelin in rats. PLoS One. 2012;7(11):e49557.

34. Dickson SL, Hrabovszky E, Hansson C, et al. Blockade of central nicotine acetylcholine receptor signaling attenuate ghrelin-induced food intake in rodents. Neuroscience. 2010;171 (4):1180-6.

35. Banks WA, Tschop M, Robinson SM, et al. Extent and direction of ghrelin transport across the blood-brain barrier is determined by its unique primary structure. J Pharmacol Exp Ther. 2002;302 (2):822-7.

36. Jerlhag E. Systemic administration of ghrelin induces conditioned place preference and stimulates accumbal dopamine. Addict Biol. 2008;13(3-4):358-63.

37. Quarta D, Di Francesco C, Melotto S, et al. Systemic administration of ghrelin increases extracellular dopamine in the shell but not the core subdivision of the nucleus accumbens. Neurochem Int. 2009;54(2):89-94.

38. Jerlhag E, Egecioglu E, Dickson SL, et al. Glutamatergic regulation of ghrelin-induced activation of the mesolimbic dopamine system. Addict Biol. 2011;16(1):82-91.

39. Wellman PJ, Clifford PS, Rodriguez JA, et al. Brain reinforcement system function is ghrelin dependent: studies in the rat using pharmacological fMRI and intracranial self-stimulation. Addict Biol. 2012;17(5):908-19.

40. Malik S, McGlone F, Bedrossian D, et al. Ghrelin modulates brain activity in areas that control appetitive behavior. Cell Metab. 2008;7(5):400-9.

41. Jerlhag E, Egecioglu E, Dickson SL, et al. Alpha-conotoxin MIIsensitive nicotinic acetylcholine receptors are involved in mediating the ghrelin-induced locomotor stimulation and dopamine overflow in nucleus accumbens. Eur Neuropsychopharmacol. 2008;18(7):508-18.

42. Larsson A, Jerlhag E, Svensson L, et al. Is an alpha-conotoxin MII-sensitive mechanism involved in the neurochemical, stimulatory, and rewarding effects of ethanol? Alcohol. 2004; 34(2-3):239-50.

43. Larsson A, Svensson L, Soderpalm B, et al. Role of different nicotinic acetylcholine receptors in mediating behavioral and 
neurochemical effects of ethanol in mice. Alcohol. 2002;28 (3): 157-67.

44. Lof E, Olausson P, deBejczy A, et al. Nicotinic acetylcholine receptors in the ventral tegmental area mediate the dopamine activating and reinforcing properties of ethanol cues. Psychopharmacology (Berl). 2007;195(3):333-43.

45. Steensland P, Simms JA, Holgate J, et al. Varenicline, an alpha4beta2 nicotinic acetylcholine receptor partial agonist, selectively decreases ethanol consumption and seeking. Proc Natl Acad Sci USA. 2007;104(30):12518-23.

46. McKee SA, Harrison EL, O'Malley SS, et al. Varenicline reduces alcohol self-administration in heavy-drinking smokers. Biol Psychiatry. 2009;66(2):185-90.

47. Mitchell JM, Teague $\mathrm{CH}$, Kayser AS, et al. Varenicline decreases alcohol consumption in heavy-drinking smokers. Psychopharmacology (Berl). 2012;223(3):299-306.

48. Skibicka KP, Shirazi RH, Hansson C, et al. Ghrelin interacts with neuropeptide Y Y1 and opioid receptors to increase food reward. Endocrinology. 2012;153(3):1194-205.

49. Robinson TE, Berridge KC. The neural basis of drug craving: an incentive-sensitization theory of addiction. Brain Res Brain Res Rev. 1993;18(3):247-91.

50. Hansson C, Shirazi RH, Naslund J, et al. Ghrelin influences novelty seeking behavior in rodents and men. PLoS One. 2012;7(12):e50409.

51. Carroll ME, France CP, Meisch RA. Food deprivation increases oral and intravenous drug intake in rats. Science. 1979;205 (4403):319-21.

52. Carroll ME, Lac ST. Dietary additives and the acquisition of cocaine self-administration in rats. Psychopharmacology. 1998;137(1):81-9.

53. Wolfe WL, Maisto SA. The relationship between eating disorders and substance use: moving beyond co-prevalence research. Clin Psychol Rev. 2000;20(5):617-31.

54. Thiele TE, Navarro M, Sparta DR, et al. Alcoholism and obesity: overlapping neuropeptide pathways? Neuropeptides. 2003;37(6):321-37.

55. Jerlhag E, Egecioglu E, Landgren S, et al. Requirement of central ghrelin signaling for alcohol reward. Proc Natl Acad Sci USA. 2009;106(27):11318-23.

56. Landgren S, Simms JA, Hyytia P, et al. Ghrelin receptor (GHSR1A) antagonism suppresses both operant alcohol self-administration and high alcohol consumption in rats. Addict Biol. 2012;17(1):86-94.

57. Bahi A, Tolle V, Fehrentz JA, et al. Ghrelin knockout mice show decreased voluntary alcohol consumption and reduced ethanol-induced conditioned place preference. Peptides. 2013; 43:48-55.

58. Kaur S, Ryabinin AE. Ghrelin receptor antagonism decreases alcohol consumption and activation of perioculomotor urocortin-containing neurons. Alcohol Clin Exp Res. 2010;34(9): 1525-34.

59. Suchankova P, Steensland P, Fredriksson I, et al. Ghrelin receptor (GHS-R1A) antagonism suppresses both alcohol consumption and the alcohol deprivation effect in rats following long-term voluntary alcohol consumption. PLoS One. 2013; 8(8):e71284.

60. Jerlhag E, Landgren S, Egecioglu E, et al. The alcohol-induced locomotor stimulation and accumbal dopamine release is suppressed in ghrelin knockout mice. Alcohol. 2011;45(4):341-7.

61. Lyons AM, Lowery EG, Sparta DR, et al. Effects of food availability and administration of orexigenic and anorectic agents on elevated ethanol drinking associated with drinking in the dark procedures. Alcohol Clin Exp Res. 2008;32(11): 1962-8.
62. Jerlhag E, Ivanoff L, Vater A et al. Peripherally circulating ghrelin does not mediate alcohol-induced reward and alcohol intake in rodents. ACER. 2013 (in press).

63. Jiang H, Betancourt L, Smith RG. Ghrelin amplifies dopamine signaling by cross talk involving formation of growth hormone secretagogue receptor/dopamine receptor subtype 1 heterodimers. Mol Endocrinol. 2006;20(8):1772-85.

64. Kern A, Albarran-Zeckler R, Walsh HE, et al. Apo-ghrelin receptor forms heteromers with DRD2 in hypothalamic neurons and is essential for anorexigenic effects of DRD2 agonism. Neuron. 2012;73(2):317-32.

65. Holst B, Cygankiewicz A, Jensen TH, et al. High constitutive signaling of the ghrelin receptor-identification of a potent inverse agonist. Mol Endocrinol. 2003;17(11):2201-10.

66. Cruz MT, Herman MA, Cote DM, et al. Ghrelin increases GABAergic transmission and interacts with ethanol actions in the rat central nucleus of the amygdala. Neuropsychopharmacology. 2013;38(2):364-75.

67. Hansson C, Alvarez-Crespo M, Taube M, et al. Influence of ghrelin on the central serotonergic signaling system in mice. Neuropharmacology. 2014;79:498-505.

68. Landgren S, Simms JA, Thelle DS, et al. The ghrelin signalling system is involved in the consumption of sweets. PLoS One. 2011;6(3):e18170.

69. Calissendorff J, Danielsson O, Brismar K, et al. Inhibitory effect of alcohol on ghrelin secretion in normal man. Eur J Endocrinol. 2005;152(5):743-7.

70. Calissendorff J, Danielsson O, Brismar K, et al. Alcohol ingestion does not affect serum levels of peptide YY but decreases both total and octanoylated ghrelin levels in healthy subjects. Metab Clin Exp. 2006;55(12):1625-9.

71. Zimmermann US, Buchmann A, Steffin B, et al. Alcohol administration acutely inhibits ghrelin secretion in an experiment involving psychosocial stress. Addict Biol. 2007;12(1):17-21.

72. Calissendorff J, Gustafsson T, Holst JJ, et al. Alcohol intake and its effect on some appetite-regulating hormones in man: influence of gastroprotection with sucralfate. Endocr Res. 2012;37 (3): $154-62$

73. Leggio L, Schwandt ML, Oot EN, et al. Fasting-induced increase in plasma ghrelin is blunted by intravenous alcohol administration: a within-subject placebo-controlled study. Psychoneuroendocrinology. 2013;38(12):3085-91.

74. Addolorato G, Capristo E, Leggio L, et al. Relationship between ghrelin levels, alcohol craving, and nutritional status in current alcoholic patients. Alcohol Clin Exp Res. 2006;30(11):1933-7.

75. Badaoui A, De Saeger C, Duchemin J, et al. Alcohol dependence is associated with reduced plasma and fundic ghrelin levels. Eur J Clin Invest. 2008;38(6):397-403.

76. Kraus T, Schanze A, Groschl M, et al. Ghrelin levels are increased in alcoholism. Alcohol Clin Exp Res. 2005;29(12): 2154-7.

77. Szulc M, Mikolajczak PL, Geppert B, et al. Ethanol affects acylated and total ghrelin levels in peripheral blood of alcoholdependent rats. Addict Biol. 2013;18(4):689-701.

78. Kim DJ, Yoon SJ, Choi B, et al. Increased fasting plasma ghrelin levels during alcohol abstinence. Alcohol Alcohol. 2005;40(1):76-9.

79. Wurst FM, Graf I, Ehrenthal HD, et al. Gender differences for ghrelin levels in alcohol-dependent patients and differences between alcoholics and healthy controls. Alcohol Clin Exp Res. 2007;31(12):2006-11.

80. Koopmann A, von der Goltz C, Grosshans M, et al. The association of the appetitive peptide acetylated ghrelin with alcohol craving in early abstinent alcohol dependent individuals. Psychoneuroendocrinology. 2012;37(7):980-6. 
81. Leggio L, Ferrulli A, Cardone S, et al. Ghrelin system in alcohol-dependent subjects: role of plasma ghrelin levels in alcohol drinking and craving. Addict Biol. 2012;17(2):452-64.

82. Leggio L, Zywiak WH, Fricchione SR et al., Intravenous ghrelin administration increases alcohol craving in alcohol-dependent heavy drinkers: a preliminary investigation. Biol Psychiatry. 2014.

83. Landgren S, Jerlhag E, Zetterberg H, et al. Association of proghrelin and GHS-R1A gene polymorphisms and haplotypes with heavy alcohol use and body mass. Alcohol Clin Exp Res. 2008;32(12):2054-61.

84. Landgren S, Jerlhag E, Hallman J, et al. Genetic variation of the ghrelin signaling system in females with severe alcohol dependence. Alcohol Clin Exp Res. 2010;34(9):1519-24.

85. Landgren S, Berglund K, Jerlhag E, et al. Reward-related genes and personality traits in alcohol-dependent individuals: a pilot case control study. Neuropsychobiology. 2011;64(1):38-46.

86. Wellman PJ, Davis KW, Nation JR. Augmentation of cocaine hyperactivity in rats by systemic ghrelin. Regul Pept. 2005;125 (1-3):151-4.

87. Davis KW, Wellman PJ, Clifford PS. Augmented cocaine conditioned place preference in rats pretreated with systemic ghrelin. Regul Pept. 2007;140(3):148-52.

88. Tessari M, Catalano A, Pellitteri M, et al. Correlation between serum ghrelin levels and cocaine-seeking behaviour triggered by cocaine-associated conditioned stimuli in rats. Addict Biol. 2007;12(1):22-9.

89. Jerlhag E, Egecioglu E, Dickson SL, et al. Ghrelin receptor antagonism attenuates cocaine- and amphetamine-induced locomotor stimulation, accumbal dopamine release, and conditioned place preference. Psychopharmacology (Berl). 2010;211 (4):415-22.

90. Clifford PS, Rodriguez J, Schul D, et al. Attenuation of cocaineinduced locomotor sensitization in rats sustaining genetic or pharmacologic antagonism of ghrelin receptors. Addict Biol. 2012;17(6):956-63.

91. Abizaid A, Mineur YS, Roth RH, et al. Reduced locomotor responses to cocaine in ghrelin-deficient mice. Neuroscience. 2011;192:500-6.

92. Gualillo O, Caminos JE, Nogueiras R, et al. Effect of food restriction on ghrelin in normal-cycling female rats and in pregnancy. Obes Res. 2002;10(7):682-7.

93. Jerlhag E, Engel JA. Ghrelin receptor antagonism attenuates nicotine-induced locomotor stimulation, accumbal dopamine release and conditioned place preference in mice. Drug Alcohol Depend. 2011;117(2-3):126-31.

94. Wellman PJ, Clifford PS, Rodriguez J, et al. Pharmacologic antagonism of ghrelin receptors attenuates development of nicotine induced locomotor sensitization in rats. Regul Pept. 2011;172(1-3):77-80.

95. Suchankova P, Jerlhag E, Jayaram-Lindstrom N, et al. Genetic variation of the ghrelin signalling system in individuals with amphetamine dependence. PLoS One. 2013;8(4):e61242.

96. Novak U, Wilks A, Buell G, et al. Identical mRNA for preproglucagon in pancreas and gut. Eur J Biochem. 1987;164(3): $553-8$.

97. Alvarez E, Roncero I, Chowen JA, et al. Expression of the glucagon-like peptide-1 receptor gene in rat brain. J Neurochem. 1996;66(3):920-7.

98. Brubaker PL, Anini Y. Direct and indirect mechanisms regulating secretion of glucagon-like peptide-1 and glucagon-like peptide-2. Can J Physiol Pharmacol. 2003;81(11):1005-12.

99. Hayes MR, Skibicka KP, Grill HJ. Caudal brainstem processing is sufficient for behavioral, sympathetic, and parasympathetic responses driven by peripheral and hindbrain glucagon-likepeptide-1 receptor stimulation. Endocrinology. 2008;149(8): 4059-68.
100. Langhans W. Anorexia of infection: current prospects. Nutrition. 2000;16(10):996-1005.

101. Naslund E, Schmidt PT, Hellstrom PM. Gut peptide hormones: importance for food intake. Scand J Gastroenterol. 2005;40(3): 250-8.

102. Tang-Christensen M, Larsen PJ, Goke R, et al. Central administration of GLP-1-(7-36) amide inhibits food and water intake in rats. Am J Physiol. 1996;271(4 Pt 2):R848-56.

103. Turton MD, O'Shea D, Gunn I, et al. A role for glucagon-like peptide-1 in the central regulation of feeding. Nature. 1996;379 (6560):69-72.

104. Kreymann B, Williams G, Ghatei MA, et al. Glucagon-like peptide-1 7-36: a physiological incretin in man. Lancet. 1987;2 (8571):1300-4.

105. Holst JJ, Seino Y. GLP-1 receptor agonists: targeting both hyperglycaemia and disease processes in diabetes. Diabetes Res Clin Pract. 2009;85(1):1-3.

106. Matsuyama T, Komatsu R, Namba M, et al. Glucagon-like peptide-1 (7-36 amide): a potent glucagonostatic and insulinotropic hormone. Diabetes Res Clin Pract. 1988;5(4):281-4.

107. Gutniak M, Orskov C, Holst JJ, et al. Antidiabetogenic effect of glucagon-like peptide-1 (7-36) amide in normal subjects and patients with diabetes mellitus. N Engl J Med. 1992;326(20): 1316-22.

108. Shughrue PJ, Lane MV, Merchenthaler I. Glucagon-like peptide-1 receptor (GLP1-R) mRNA in the rat hypothalamus. Endocrinology. 1996;137(11):5159-62.

109. Hayes MR, Bradley L, Grill HJ. Endogenous hindbrain glucagon-like peptide-1 receptor activation contributes to the control of food intake by mediating gastric satiation signaling. Endocrinology. 2009;150(6):2654-9.

110. Merchenthaler I, Lane M, Shughrue P. Distribution of pre-pro-glucagon and glucagon-like peptide-1 receptor messenger RNAs in the rat central nervous system. J Comp Neurol. 1999;403(2):261-80.

111. Alhadeff AL, Rupprecht LE, Hayes MR. GLP-1 neurons in the nucleus of the solitary tract project directly to the ventral tegmental area and nucleus accumbens to control for food intake. Endocrinology. 2012;153(2):647-58.

112. Egecioglu E, Steensland P, Fredriksson I, et al. The glucagon-like peptide 1 analogue exendin- 4 attenuates alcohol mediated behaviors in rodents. Psychoneuroendocrinology. 2013;38(8):1259-70.

113. Shirazi RH, Dickson SL, Skibicka KP. Gut peptide GLP-1 and its analogue, exendin-4, decrease alcohol intake and reward. PLoS One. 2013;8(4):e61965.

114. Davis JF, Schurdak JD, Magrisso IJ, et al. Gastric bypass surgery attenuates ethanol consumption in ethanol-preferring rats. Biol Psychiatry. 2012;72(5):354-60.

115. Erreger K, Davis AR, Poe AM, et al. Exendin-4 decreases amphetamine-induced locomotor activity. Physiol Behav. 2012;106(4):574-8.

116. Graham DL, Erreger K, Galli A, et al. GLP-1 analog attenuates cocaine reward. Mol Psychiatry. 2013;18(9):961-2.

117. Egecioglu E, Engel JA, Jerlhag E. The glucagon-like peptide 1 analogue, exendin-4, attenuates the rewarding properties of psychostimulant drugs in mice. PLoS One. 2013;8(7):e69010.

118. Egecioglu E, Engel JA, Jerlhag E. The glucagon-like peptide 1 analogue exendin- 4 attenuates the nicotine-induced locomotor stimulation, accumbal dopamine release, conditioned place preference as well as the expression of locomotor sensitization in mice. PLoS One. 2013;8(10):e77284.

119. Blednov YA, Walker D, Harris RA. Blockade of the leptinsensitive pathway markedly reduces alcohol consumption in mice. Alcohol Clin Exp Res. 2004;28(11):1683-92.

120. Kiefer F, Jahn H, Wolf K, et al. Free-choice alcohol consumption in mice after application of the appetite regulating peptide leptin. Alcohol Clin Exp Res. 2001;25(5):787-9. 
121. Kiefer F, Jahn H, Otte C, et al. Increasing leptin precedes craving and relapse during pharmacological abstinence maintenance treatment of alcoholism. J Psychiatr Res. 2005;39(5): 545-51.

122. Nicolas JM, Fernandez-Sola J, Fatjo F, et al. Increased circulating leptin levels in chronic alcoholism. Alcohol Clin Exp Res. 2001;25(1):83-8.

123. Obradovic T, Meadows GG. Chronic ethanol consumption increases plasma leptin levels and alters leptin receptors in the hypothalamus and the perigonadal fat of C57BL/6 mice. Alcohol Clin Exp Res. 2002;26(2):255-62.

124. Lawrence AJ, Cowen MS, Yang HJ, et al. The orexin system regulates alcohol-seeking in rats. Br J Pharmacol. 2006;148(6): 752-9.

125. Richards JK, Simms JA, Steensland P, et al. Inhibition of orexin1/hypocretin-1 receptors inhibits yohimbine-induced reinstatement of ethanol and sucrose seeking in Long-Evans rats. Psychopharmacology (Berl). 2008;199(1):109-17.

126. Hamlin AS, Newby J, McNally GP. The neural correlates and role of D1 dopamine receptors in renewal of extinguished alcohol-seeking. Neuroscience. 2007;146(2):525-36.

127. Brown RM, Lawrence AJ. Ascending orexinergic pathways and alcohol-seeking. Curr Opin Neurobiol. 2013;23(4):467-72.

128. Boutrel B, Kenny PJ, Specio SE, et al. Role for hypocretin in mediating stress-induced reinstatement of cocaine-seeking behavior. Proc Natl Acad Sci USA. 2005;102(52):19168-73.

129. Harris GC, Wimmer M, Aston-Jones G. A role for lateral hypothalamic orexin neurons in reward seeking. Nature. 2005;437(7058):556-9.

130. Smith RJ, Aston-Jones G. Orexin/hypocretin 1 receptor antagonist reduces heroin self-administration and cue-induced heroin seeking. Eur J Neurosci. 2012;35(5):798-804.

131. von der Goltz C, Koopmann A, Dinter C, et al. Orexin and leptin are associated with nicotine craving: a link between smoking, appetite and reward. Psychoneuroendocrinology. 2010;35(4): $570-7$.

132. Borgland SL, Taha SA, Sarti F, et al. Orexin A in the VTA is critical for the induction of synaptic plasticity and behavioral sensitization to cocaine. Neuron. 2006;49(4):589-601.

133. Leshan RL, Opland DM, Louis GW, et al. Ventral tegmental area leptin receptor neurons specifically project to and regulate cocaine- and amphetamine-regulated transcript neurons of the extended central amygdala. J Neurosci. 2010;30(16):5713-23.

134. Opland DM, Leinninger GM, Myers MG Jr. Modulation of the mesolimbic dopamine system by leptin. Brain Res. 2010;1350: $65-70$.
135. Thiele TE, Marsh DJ, Ste Marie L, et al. Ethanol consumption and resistance are inversely related to neuropeptide $\mathrm{Y}$ levels. Nature. 1998;396(6709):366-9.

136. Thorsell A, Rimondini R, Heilig M. Blockade of central neuropeptide Y (NPY) Y2 receptors reduces ethanol self-administration in rats. Neurosci Lett. 2002;332(1):1-4.

137. Rimondini R, Thorsell A, Heilig M. Suppression of ethanol selfadministration by the neuropeptide Y (NPY) Y2 receptor antagonist BIIE0246: evidence for sensitization in rats with a history of dependence. Neurosci Lett. 2005;375(2):129-33.

138. Thorsell A, Repunte-Canonigo V, O'Dell LE, et al. Viral vectorinduced amygdala NPY overexpression reverses increased alcohol intake caused by repeated deprivations in Wistar rats. Brain. 2007;130(Pt 5):1330-7.

139. Cippitelli A, Damadzic R, Hansson AC, et al. Neuropeptide Y (NPY) suppresses yohimbine-induced reinstatement of alcohol seeking. Psychopharmacology (Berl). 2010;208(3):417-26.

140. Hillemacher T, Weinland C, Heberlein A, et al. Increased levels of adiponectin and resistin in alcohol dependence-possible link to craving. Drug Alcohol Depend. 2009;99(1-3):333-7.

141. Kulkosky PJ. Effect of cholecystokinin octapeptide on ethanol intake in the rat. Alcohol. 1984;1(2):125-8.

142. Toth P, Shaw C, Perlanski E, et al. Cholecystokinin octapeptide reduces ethanol intake in food- and water-sated rats. Pharmacol Biochem Behav. 1990;35(2):493-5.

143. Kulkosky PJ, Clayborne YJ, Sandoval SL. Cholecystokinin and bombesin inhibit ethanol and food intake in rats selectively bred for ethanol sensitivity. Alcohol Clin Exp Res. 1993;17(3): 545-51.

144. Crespi F. The role of cholecystokinin (CCK), CCK-A or CCK-B receptor antagonists in the spontaneous preference for drugs of abuse (alcohol or cocaine) in naive rats. Methods Find Exp Clin Pharmacol. 1998;20(8):679-97.

145. Lewis MJ, Johnson DF, Waldman D, et al. Galanin microinjection in the third ventricle increases voluntary ethanol intake. Alcohol Clin Exp Res. 2004;28(12):1822-8.

146. Rada P, Avena NM, Leibowitz SF, et al. Ethanol intake is increased by injection of galanin in the paraventricular nucleus and reduced by a galanin antagonist. Alcohol. 2004;33(2):91-7.

147. Edwards S, Kenna GA, Swift RM, et al. Current and promising pharmacotherapies, and novel research target areas in the treatment of alcohol dependence: a review. Curr Pharm Des. 2011;17(14):1323-32.

148. Rodriguez FD, Covenas R. Targeting opioid and neurokinin-1 receptors to treat alcoholism. Curr Med Chem. 2011;18(28): 4321-34. 